УДК 378.14.1.1

DOI https://doi.org/10.32840/1992-5786.2020.72-1.11

\author{
Г. Б. Лоїк \\ кандидат педагогічних наук, доцент, \\ заступник директора з навчально-виховної роботи \\ Львівської фрілії \\ Київського університету культури і мистецтв
}

\title{
ПЕРСПЕКТИВИ РОЗВИТКУ ІНКЛЮЗИВНОЇ ОСВІТИ В УКРАЇНІ
}

У статті розглянуто проблему становлення і розвитку інклюзивної освіти в Україні на сучасному етапі. Потреба в інклюзивній освіті підтверджується нормативно-правовими документами з цієї проблеми. Показана актуальність проблеми, яка зумовлена посиленням необхідності реформування освіти з метою підвищення профресійної компетентності фрахівців. Підкреслено, що в освітній процес дедалі більще вводиться принцип гуманізації. Адже Україна є державою, де значна увага приділяється початковій і дошкільній освіті. Особливу увагу звертають саме на фрахівців з інклюзивної освіти. Це зумовлює потребу підвищення рівня професійної підготовки майбутніх фрахівців з інклюзивної освіти, яка розалядається як багатофракторна структура і починається з дошкільної освіти. Під інклюзивною освітою розуміють систему послуг, яка охоплює підготовку дітей з особливими потребами в їх психофрізичному розвитку. Визначено можливості для створення освітнього середовища, в якому будуть розвиватися діти з особливими потребами. Це гнучка, індивідуалізована система навчання дітей з особливими потребами. Вона є індивідуальною, пристосованою до умов масової загальноосвітньої школи за місцем проживання, при цьому забезпечується медико-соціальним та психолого-педагогічним супроводом. Новий погляд на інклюзивну освіту в Україні було сфрормульовано у 2010 році, що зумовило новий етап становлення "освіти для всіх». За Наказом Міністерства освіти і науки була затверджена Концепція розвитку інклюзивного навчання - на наш погляд, це один із потужніших проектів, який передбачає виконання конкретних завдань для інклюзії в галузі освіти. Тобто нині передбачається запровадження інклюзивного навчання дітей з особливими потребами, яке може бути здійснене шляхом фрормування нової фрілософрії державної політики щодо дітей з особливими освітніми потребами.

Ключові слова: інклюзивна освіта, дошкільна освіта, заклад вищої освіти, фрахівці, інклюзивне середовище, засоби.

Постановка проблеми. Нині розвиток суспільства дедалі більше спрямовується на закріплення уявлень про цінності людства. Наша освіта більше уваги приділяє підготовці до життя дітей, які мають вади розвитку. Науковці досліджують можливі шляхи забезпечення певного рівня готовності таких дітей до майбутньої професійної діяльності. Вимоги дотримання норм людського співжиття, принципів солідарності, відображені у Резолюції Генеральної Асамблеї ООН від 12 грудня 1997 року, базуються на принципах доступності освіти для всіх. Принцип спрямовує увагу на те, що допомога людям з інвалідністю, їх адаптація в соціумі $\epsilon$ одним із завдань освіти. Тоді люди із психофрізичними порушеннями матимуть змогу здобувати освіту в доступній для себе сфрері.

Інклюзивна освіта набуває дедалі більшого поширення на теренах України. Це пояснюється тим, що щороку зростає кількість дітей із певними фізичними і розумовими відхиленнями. Але вони члени нашого суспільства і потрібно забезпечити їм доступ до освіти, як загальної, так і профресійної. Цим забезпечується їх майбутнє. Розвиток в Україні шкіл з інклюзивною освітою сприяє цьому процесу. Такі школи потребують спеціально підготовлених учителів, вихователів, нових специфічних програм, сучасних засобів навчання. Тому важливе значення мають дослідження розвитку інклюзивної освіти.

Аналіз останніх досліджень і публікацій. Наукові праці вітчизняних і закордонних фрахівців у галузі інклюзивної освіти висвітлюють загальнотеоретичні положення цього напряму освіти. Організаційно-педагогічні аспекти інклюзивної освіти розглянуто в працях Н. Артюшенко, І. Дмитрієва, Л. Зданевич, Ю. Сак, В. Синьов, М. Семаго, Н. Суховієнко, А. Шевцова та ін.; питання спільного навчання дітей із психофізичними порушеннями та їх здоровими однолітками розглянуто в роботах Н. Бєлопольської, Є. Дмітрієва, Н. Назарова, М. Супрун, У. Ульєнкова, Л. Шипіцина та ін.; особливості психолого-педагогічного супроводу в умовах інклюзії визначали у дослідженнях С. Сорокоумова, Т. Зубарєва, Л. Олтаржевська; значна увага приділена формуванню професійної готовності майбутніх учителів до інклюзивної освіти в дослідженнях С. Миронова, І. Россіхіна, М. Шеремет та ін. Але проблема інклюзивної освіти потребує подальшого освіження.

Мета статті - розглянути основні положення, на яких базується процес інклюзивної освіти, і визначити перспективи подальшого її розвитку в Україні. 
Виклад основного матеріалу. Проводячи теоретичний огляд проблеми інклюзивної освіти, було визначено, що ця проблема в центрі уваги як науковців, так і громадськості. Підтвердженням цьому стало створення під егідою ЄНЕСКО у 1993 році «Міжнародної комісії з освіти для XXI століття» [1, с. 3].

Актуальність проблеми зумовлена тим, що нині посилилась необхідність реформувати, що пов'язано з підвищенням вимог до професійної компетентності фахівців. Одночасно в освітній процес дедалі більше вводиться принцип гуманізації. Україна $є$ однією з країн, в якій значна увага приділяється початковій і дошкільній освіті, зокрема фрахівцям $з$ інклюзивної освіти. «Нові реалії, орієнтація українського суспільства на демократичні принципи, реорганізація системи дошкільної освіти (зміна співвідношення родинного і суспільного дошкільного виховання, урізноманітнення його форм, багатоваріантність освітньо-виховних програм) зумовлюють необхідність змін і в системі підготовки фрахівців дошкільної освіти» [9, с. 28-34]. Це пояснює необхідність підвищення рівня професійної підготовки майбутніх фахівців з інклюзивної освіти, яка розглядається як багатофракторна структура і починається з дошкільної освіти [10, с. 125].

Під інклюзивною освітою розуміють систему послуг, яка охоплює підготовку дітей з особливими потребами в плані психофізичного розвитку в різних умовах проживання. Це вимагає створення освітнього середовища, яке буде відповідати потребам інклюзивної освіти. Це гнучка, індивідуалізована система навчання дітей з особливостями потребами. Вона $є$ індивідуальною, пристосованою до умов масової загальноосвітньої школи за місцем проживання. При цьому забезпечується медико-соціальним та психолого-педагогічним супроводом [5, с. 24].

Новий погляд на інклюзивну освіту в Україні було сфрормульовано у 2010 році, що зумовило новий етап становлення "освіти для всіх». За Наказом Міністерства освіти і науки, була затверджена Концепція розвитку інклюзивного навчання - на наш погляд, це один із потужніших проектів, який передбачає виконання конкретних завдань для інклюзії в галузі освіти. Такий вектор розвитку передбачає запровадження інклюзивного навчання дітей з особливими потребами, який може бути здійснений через низку завдань: формування нової фрілософрії державної політики щодо дітей з особливими освітніми потребами, удосконалення нормативно-правової бази відповідно до міжнародних договорів у сфері прав людини, реалізації та поширення моделі інклюзивного навчання дітей у дошкільних та загальноосвітніх навчальних закладах [8].

Основними принципами було визначено індивідуалізацію, міжвідомчу інтеграцію та соціальне партнерство, зазначено про соціальну відповідальність сім'ї, а також принципи науковості, системності і варіативності.

Як і кожен процес, інклюзивна освіта спирається на нормативно-правову базу українського законодавства. У нормативних документах показано значущість інклюзивної освіти, можливі шляхи розвитку інклюзивної освіти та активізацію ресурсів для створення умов інклюзивного навчання. Включення дітей із вадами розвитку в освітній процес - це процес, який характеризує високорозвинені країни.

Згідно з Наказом, Концепція інклюзивного навчання $€$ можливою за умови виконання низки завдань:

- удосконалення нормативно-правового, науково-методичного, фінансово-економічного забезпечення;

- формування освітньо-розвивального середовища для дітей з особливими освітніми потребами шляхом забезпечення психолого-педагогічного, медико-соціального супроводу;

- впровадження інклюзивної моделі навчання в загальноосвітніх навчальних закладах на суспільний запит;

- запровадження інноваційних освітніх технологій у контексті інклюзивного підходу;

- розробка спеціально створеного та облаштованого соціального середовища, навчальних приміщень, навчально-дидактичного забезпечення, реабілітаційних засобів навчання;

- удосконалення системи підготовки та перепідготовки педагогічних кадрів, які здійснюють свою діяльність в умовах інклюзивного навчання;

- залучення батьків дітей з особливими освітніми потребами до участі в навчально-реабілітаційному процесі [Наказ].

Поняття «інклюзія» означає отримання більших можливостей у навчанні для усіх дітей на основі інклюзивного підходу. Інклюзивне навчання може реалізуватися в інклюзивній школі, яка є моделлю освітнього навчального закладу, з відмінністю в навчальних планах та програмах, методах і формах навчання, які адаптовані до стану фізичного і розумового розвитку дітей.

Підготовка фрахівця 3 інклюзивної освіти $€$ однією з складових частин професійної підготовки, яка володіє певними особливостями. Це насамперед стосується комплексу, який включає підготовчий процес, освітній процес із кінцевим результатом - дипломований фахівець, який володіє достатнім рівнем готовності до роботи в галузі дошкільної освіти. Це висвітлено в працях І. Кузава [7, с. 40].

І. Кузава наводить перелік недостатньої розробленості інклюзивної освіти, в чому ми підтримуємо автора, оскільки те саме показали наші дослідження: 
1) незначна кількість мережі спеціальних дошкільних закладів (груп) за місцем проживання осіб зазначеної категорії;

2) дефріцит місць у системі загальної дошкільної освіти для таких вихованців;

3) недостатнє забезпечення відповідними кваліфікованими кадрами у галузі інклюзивної освіти;

4) психологічна, професійна неготовність суспільства, загальноосвітніх дошкільних навчальних закладів та педагогів до сприйняття таких дітей та роботи з ними в умовах інклюзії;

5) відсутність належного програмно-методичного, матеріально-технічного забезпечення інклюзивної освіти дошкільників, які потребують корекції психофрізичного розвитку;

6) наявність міжвідомчих бар'єрів при організації спільного навчання та виховання дошкільників;

7) відсутність системи ранньої діагностики та медико-психолого-педагогічного супроводу.

Перелічені положення дають уявлення про актуальність проблеми впровадження інклюзивної освіти дітей різного віку в Україні.

Дослідження основ інклюзивної освіти показало, що ця проблема широко розглядається в наукових публікаціях. Це пояснюється потребою у формуванні достатнього рівня готовності фрахівців до практичної діяльності. Турбота про включення дітей з обмеженим розумовим і фізичним розвитком у загальноосвітній простір є загальноприйнятою нормою. У нормативних документах стосовно освіти серед пріоритетів визначають право дітей із психофрізичними порушеннями на освіту, медичне обслуговування, професійну підготовку та трудову діяльність. У зв'язку зі зміною суспільства, новими умовами для розвитку освіти дітей і дорослих виникла потреба дослідити нові підходи щодо їх освіти, особливо дітей з обмеженими можливостями. Це такі підходи, що сприяють задоволенню потреб їх розвитку, впровадженню сучасних форм і методів в освітній процес, покращують процеси абілітації та реабілітації, формують адаптовану особистість, сприяючи ії інтеграції в суспільство.

Серед праць, присвячених проблемі розвитку інклюзивної освіти, ми виділяємо праці Н. Артюшенка, Н. Білопольської, В. Бондара, І. Дмитрієвої, Т. Сак, В. Синьова, Н. Суховієнка, А. Шевцова. У працях цих науковців обґрунтовано положення щодо особливостей розвитку психо-фрізіологічних процесів у дітей різного віку, механізмів формування їх соціально-комунікативної активності та вмінь перебувати в дитячому колективі. Але проблема забезпечення якісної інклюзивної освіти потребує додаткового розгляду. Це насамперед стосується дошкільної освіти. Адже, якщо в молодшому віці правильно організувати процес навчання дітей із вадами розвитку, то вони в подальшому зможуть легше увійти в навчальний процес загальноосвітньої школи.
У психолого-педагогічній літературі професійна підготовка педагогів визначається як системне утворення з пов'язаних між собою компонентів, що є впорядкованими поєднанням, яке характеризується певною цілісністю, розгалуженими зв'язками, відношеннями із зовнішнім середовищем за наявності суб'єкта та об'єкта. Тобто це процес фахового становлення майбутніх педагогів у вищому навчальному закладі [6, с. 17-22].

Поняття «професійна підготовка» майбутнього вихователя, за поданням Л. Зданевич, - це спеціально організований освітній процес, спрямований на формування в майбутніх фрахівців високого рівня готовності до ефективного здійснення професійної діяльності в галузі дошкільної освіти [4, с. 44].

У 2012 році в Закон України про права інвалідів (ст. 21) було внесено таке доповнення: «Навчальні заклади надають освітні послуги інвалідам нарівні з іншими громадянами, в тому числі шляхом створення належного кадрового, матеріально-технічного забезпечення та забезпечення розумного пристосування, що враховує індивідуальні потреби інваліда» [2], встановлено, що «жестова мова як мова осіб із вадами слуху є засобом спілкування та навчання і захищається державою». Це засвідчує визнання інклюзивного компонента та важливість створення рівних умов для дітей із різними потребами в українській спільноті. Указом Президента України «Про заходи щодо забезпечення пріоритетного розвитку освіти в Україні» № 926/2010 від 30 вересня 2010 року скоординовано «забезпечити активізацію роботи із запровадження інклюзивного навчання в дошкільних i загальноосвітніх навчальних закладах дітей з особливими потребами» [13].

У дітей із фізичними вадами спілкування 3 дорослими й іншими дітьми може викликати низку труднощів через володіння засобами комунікації та масової інформації. Тому важливим став Указ Президента України «Про заходи щодо розв'язання актуальних проблем осіб з обмеженими фрізичними можливостями», в якому міститься орієнтир на діяльність щодо вживання «заходів щодо розширення застосування у сфері освіти дактильно-жестової мови як засобу спілкування інвалідів із вадами слуху, забезпечити доступ таких осіб до засобів масової інфооммації через титрування та здійснення сурдоперекладу на дактильно-жестову мову інформаційних і тематичних телепрограм, кіно- та відеофрільмів» [11].

Значну роль у розвитку інклюзивної освіти відіграв документ про зміни в педагогічній структурі. У 2012 році Кабінет Міністрів України дав Розпорядження «Про затвердження плану заходів щодо запровадження інклюзивного та інтегрованого навчання у загальноосвітніх навчальних закладах», в якому висувалася вимога включити 
у навчальні програми вищих навчальних закладів, які здійснюють підготовку фахівців за напрямом «Педагогічна освіта», курс «Дидактика інклюзивного навчання». Відповідно до Закону України «Про внесення змін до законодавчих актів із питань загальної середньої та дошкільної освіти щодо організації навчально-виховного процесу», з 2010 року в загальноосвітніх навчальних закладах запроваджується інклюзивне навчання. Таким чином, навчальні плани вищих навчальних закладів доповнилися дисципліною «Основи інклюзивної освіти» [3].

Варто зазначити, що в законах України «Про державні соціальні стандарти та державні соціальні гарантії», «Про охорону дитинства», «Про основи соціальної захищеності інвалідів в Україні», «Про реабілітацію інвалідів в Україні», «Про соціальні послуги», встановлено та регламентовано надання послуг у соціальній галузі, галузям медицини та освіти особам з обмеженими можливостями здоров'я, зокрема, дітям з особливими освітніми потребами. Згідно з Конституцією України та законодавством у галузі освіти, реабілітації та соціального захисту, держава має забезпечити доступність до якісної освіти відповідного рівня дітям з особливими освітніми потребами 3 урахуванням здібностей, можливостей, бажань та інтересів кожної дитини шляхом запровадження інклюзивної освіти. Приєднавшись до основних міжнародних договорів у сфері прав людини, серед яких Декларація ООН про права людини, Конвенції ООН про права інвалідів, про права дитини, Україна взяла зобов'язання дотримуватися загальнолюдських прав, зокрема, щодо забезпечення права на освіту дітей з особливими освітніми потребами нарівні з іншими дітьми.

Таким чином інклюзія, інклюзивна форма навчання та інклюзивна освіта підтримуються владою України на законодавчому, проєктному і певною мірою фінансовому рівнях та орієнтує українське суспільство на визнання необхідності створення рівних освітніх та соціальних умов для всіх.

Висновки і пропозиції. На основі теоретичних і практичних досліджень було визначено роль інклюзивної освіти в розвитку дітей з вадами психічного і розумового розвитку. Розглянуто один із шляхів підвищення якості розвитку такої освіти підготовка вчителів до роботи в умовах інклюзивної освіти, вдосконалення засобів навчання, які враховують особливості підготовки таких дітей.

У перспективах будемо досліджувати специфіку професійної підготовки майбутніх вихователів і вчителів в умовах інклюзивної освіти.

\section{Список використаної літератури:}

1. Вульфсон Б.Л. Стратегия развития образования на Западе на пороге XXI века = Educational strategy in the West: toward the XXI century / Ун-т Рос. Акад. Образования. Москва : Изд-во УРАО, 1999. 204 с.

2. Закон України «Про внесення змін до деяких законів України щодо прав інвалідів». Відомості Верховної Ради України (ВВР). 2012. N 31. Ст. 381. URL: http://zakon2.rada.gov.ua/ laws/show/4213-17

3. Закон України Про внесення змін до деяких законів України про освіту щодо організації інклюзивного навчання. URL: http://zakon2. rada.gov.ua/laws/show/1324-18

4. Зданевич Л.В. Теоретичні і методичні основи професійної підготовки майбутніх вихователів дошкільних навчальних закладів до роботи з дезадаптованими дітьми : автореф. дис. ... д-ра пед. наук : 13.00.04 «Теорія і методика профресійної освіти». Житомир, 2014. 44 с.

5. Колупаєва А.А. Інклюзивна освіта: реалії та перспективи : Монографія. Київ : Самміт-Книга, 2009. 272 c.

6. Косенко Ю. Система професійної підготовки педагогічних кадрів дошкільної освіти в Україні з позиції історико-педагогічного дослідження. Збірник наукових праць. Педагогічні науки. Випуск 51. Херсон : Видавництво ХДУ, 2009. С. 17-22.

7. Кузава І.Б. Теоретичні та методичні засади інклюзивної освіти дошкільників, які потребують корекції психофізичного розвитку : автореф. дис. ... докт. пед. наук : 13.00.03 / М-во освіти і науки України, Нац пед. ун-т ім. М.П. Драгоманова. Київ, 2015. 40 с.

8. Наказ Міністерства освіти і науки України «Про затвердження Концепції розвитку інклюзивного навчання» № 912 від 1 жовтня 2010 р. URL: http://osvita.ua/legislation/Ser_osv/9189/

9. Підлипняк І. Підготовка майбутніх фрахівців дошкільної освіти. Психолого-педагогічні проблеми сільської школи. 2013. № 44. С. 28-34.

10.Поніманська Т.І. Дошкільна педагогіка : навчальний посібник для студентів вищих навчальних закладів. Київ : Академвидав, 2006. 456 с.

11. Про затвердження плану заходів щодо запровадження інклюзивного та інтегрованого навчання у загальноосвітніх навчальних закладах : Розпорядження Кабінету Міністрів України від 3 грудня 2009 р. № 1482-p. URL: http://zakon3.rada.gov.ua/laws/show/1482-2009-

12.Про затвердження Концепції розвитку інклюзивного навчання : Наказ Міністерства освіти і науки України № 912 від 1 жовтня 2010 р. URL: http://osvita.ua/legislation/Ser_osv/9189/

13.Указ Президента України «Про заходи щодо забезпечення пріоритетного розвитку освіти в Україні». URL: http://zakon3.rada.gov.ua/laws/ show/926/2010 
Loik H. Prospects for the development of inclusive education in Ukraine

The article considers the problem of formation and development of inclusive education in Ukraine at the present time. The need for inclusive education is confirmed by regulations on this issue. The urgency of the problem is shown, which is due to the growing need to reform education in order to increase the professional competence of specialists. It is emphasized that the principle of humanization is increasingly being introduced into the educational process. Ukraine is a country where much attention is paid to primary and preschool education. Special attention is paid to specialists in inclusive education. This necessitates an increase in the level of professional training of future specialists in inclusive education, which is considered as a multifactorial structure and begins with preschool education. Inclusive education is a system of services that includes the training of children with special needs in their psychophysical development. Conditions have been identified for creating an educational environment in which children with special needs will develop. It is a flexible, individualized system of teaching children with special needs. It is individual, adapted to the conditions of a mass secondary school at the place of residence. At the same time medical, social, psychological and pedagogical support is provided. A new look at inclusive education in Ukraine was implemented in 2010, which led to a new stage in the formation of "education for all". By order of the Ministry of Education and Science, the Concept for the Development of Inclusive Education was approved - in our opinion, this is one of the most powerful projects, which provides for specific tasks for inclusion in the field of education. It is envisaged to introduce inclusive education for children with special needs, which can be done by forming a new philosophy of state policy on children with special educational needs.

Key words: inclusive education, preschool education, higher education institution, specialists, inclusive environment, tools. 